\title{
Anesthetic considerations for blue rubber bleb nevus syndrome: a case report
}

\author{
Mariko Aizawa*, Satoshi Ishihara and Takeshi Yokoyama
}

To the Editor,

Blue rubber bleb nevus syndrome (BRBNS) is a rare condition characterized by numerous malformations of the venous system in the skin and visceral organs [1]. Surgical resection of the gastrointestinal tract is the choice of treatment for bleeding from venous malformations [2], and it requires general anesthesia. In general, anesthetic management in patients with BRBNS is challenging because of vascular malformations, especially in the airway and spinal canal [3-5]. Here, we report the case of a patient with BRBNS who underwent open abdominal surgery with successful general and epidural anesthesia.

A 60-year-old woman with BRBNS was scheduled for curative intestinal resection via laparotomy for bleeding hemangiomas in the ileum. In addition to routine history taking and physical examinations, preoperative evaluation was focused on two main areas. First, the extent of airway involvement was evaluated. Multiple hemangiomas were found on physical examination (Fig. 1), but no previous airway bleeding or obstruction was noted. The airway was assessed using a fiber optic bronchoscope, which revealed multiple hemangiomas in the larynx and trachea (Fig. 2). Tracheal stenosis or bleeding was not noted. Second, the feasibility of epidural anesthesia was evaluated. There was no particular history or physical findings suggesting a spinal canal lesion. Additionally, we assessed the spinal canal including epidural space using magnetic resonance imaging (MRI), which revealed no vascular lesion. Typical venous hemangiomas were found in the subcutaneous tissue and muscles of the back. An epidural catheter was inserted at the T10-T11 interspace using a 17-gauge Tuohy needle after confirming the absence of lesions in the soft tissue on ultrasonography. General anesthesia was then induced. Mask ventilation was performed without any issue. Laryngoscopy and tracheal intubation were uneventfully performed using a McGRATH MAC video laryngoscope with a size 3 blade (Aircraft Medical, Edinburgh, UK), to assist in minimizing mechanical contact with the hemangiomas in the upper

\footnotetext{
* Correspondence: marikoy53@yahoo.co.jp

Department of Anesthesia, Teine Keijinkai Hospital, 1-12-1-40 Maeda, Teine, Sapporo 006-8555, Japan
}

airway. Upon intubation, using a fiber optic bronchoscope, we confirmed that the tracheal tube was not in contact with any vascular lesions of the trachea and that there was no bleeding. The surgery was completed uneventfully. The patient was extubated without disruption of any upper airway lesions. The postoperative course was uneventful.

The present case illustrates the importance of careful preoperative evaluation of the upper airway and spinal canal in patients with BRBNS. Airway management can be problematic at general anesthesia because airway hemangiomas can cause airway obstruction or bleeding [6]. As for spinal canal lesions, epidural anesthesia might cause bleeding and hematoma formation if they are overlooked.

With regard to airway evaluation, focused history taking and physical examination are essential, and use of a fiber optic bronchoscope is reasonable. Oral intubation is feasible, and video laryngoscope is useful for safe intubation $[4,5,7]$. Epidural anesthesia can be safely managed by paying attention to the possibilities of spinal canal lesions. MRI is the preferred modality for evaluating spinal canal involvement [8]. Although challenging, anesthesia can be safely performed in patients with BRBNS. Thorough preoperative evaluation based on the understanding of the nature of BRBNS is essential.

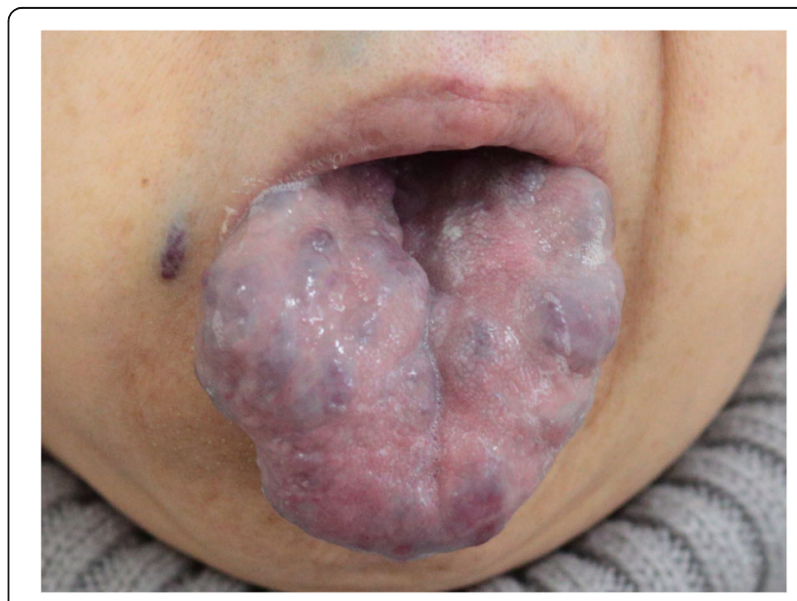

Fig. 1 Multiple hemangiomas on the tongue 

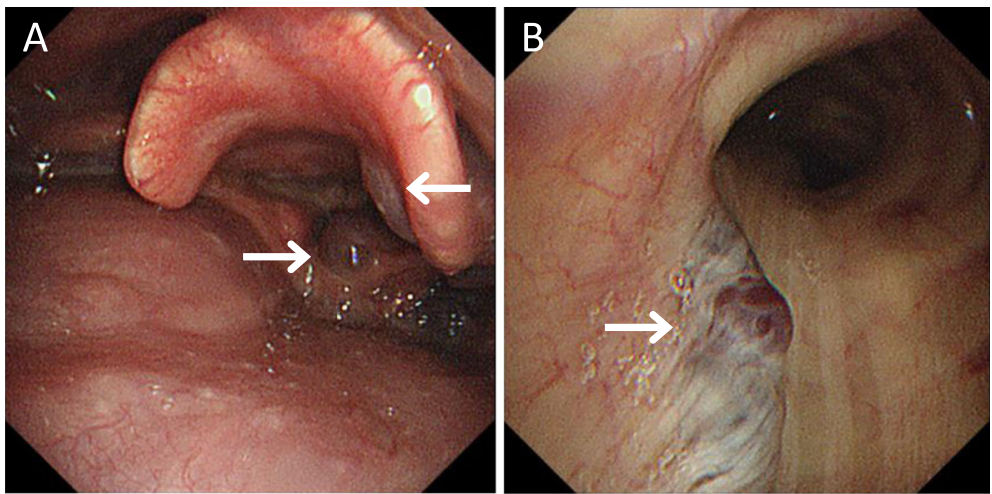

Fig. 2 Fiber optic bronchoscope showing multiple hemangiomas (a) at the epiglottic vallecula and arytenoid (white arrows) and (b) in the trachea (white arrow)

\section{Abbreviations}

BRBNS: Blue rubber bleb nevus syndrome; MRI: Magnetic resonance imaging

\section{Acknowledgement}

Not applicable.

\section{Authors' contributions}

MA collected the patient's data and drafted the manuscript. SI helped to draft the manuscript. TY reviewed the manuscript. All authors read and approved the final manuscript.

\section{Funding}

None.

\section{Availability of data and materials}

The data that support the findings of this study are available on request from the corresponding author MA.

\section{Ethics approval and consent to participate}

Not applicable.

\section{Consent for publication}

Written informed consent was obtained from the patient for publication of this case report.

\section{Competing interests}

The authors declare that they have no competing interests.

Received: 29 October 2019 Accepted: 4 December 2019

Published online: 16 December 2019

\section{References}

1. Jin XL, Wang ZH, Xiao XB, Huang LS, Zhao XY. Blue rubber bleb nevus syndrome: a case report and literature review. World J Gastroenterol. 2014 20:17254-9.

2. Fishman SJ, Smithers CJ, Folkman J, Lund DP, Burrows PE, Mulliken JB, et al. Blue rubber bleb nevus syndrome: surgical eradication of gastrointestinal bleeding. Ann Surg. 2005:241:523-8.

3. Ochiai D, Miyakoshi K, Yakubo K, Fukuiya T, Yoshimura Y. Familial blue rubber bleb nevus syndrome in pregnancy with spinal epidural involvement. Case Rep Obstet Gynecol. 2013;2013:141506.

4. Galey J, Bharadwaj S, Crimmins S, Hong CM, Malinow AM. Anesthetic implications of an obstetric patient with blue rubber bleb nevus syndrome. A Case Rep. 2016;6:146-9.

5. Ueno T, Komasawa N, Matsunami S, Majima N, Kusaka Y, Minami T Anesthetic management of a pediatric case of blue rubber bleb nevi syndrome combined with small-intestinal intussusception (in Japanese). Masui. 2016;65:384-6.

6. Adeniji AA, Fairlie FM, Jones TH, Wilkinson P. Pregnancy and blue rubber bleb naevus syndrome. Br J Obstet Gynaecol. 1999;106(12):1316-8.
7. González-Pizarro P, García-Fernández J. Blue rubber bleb nevus syndrome: airway management. Paediatr Anaesth. 2010;20:285-7.

8. Elsayes KM, Menias CO, Dillman JR, Platt JF, Willatt JM, Heiken JP. Vascular malformation and hemangiomatosis syndromes: spectrum of imaging manifestations. AJR Am J Roentgenol. 2008;190:1291-9.

\section{Publisher's Note}

Springer Nature remains neutral with regard to jurisdictional claims in published maps and institutional affiliations.

\section{Submit your manuscript to a SpringerOpen ${ }^{\circ}$ journal and benefit from:}

- Convenient online submission

- Rigorous peer review

- Open access: articles freely available online

High visibility within the field

- Retaining the copyright to your article

Submit your next manuscript at $\boldsymbol{\wedge}$ springeropen.com 